\title{
Hydrogeological, hydrochemical, and natural isotopes evaluation of groundwater and surface water interactions in the alluvial plain, tropical region of southeastern Brazil
}

\author{
Waldilene Correa ${ }^{1}$, Sueli Pereira ${ }^{1}$, Joaquim Ernesto Bernardes ${ }^{1}$, and Paulo Ricardo Pereira ${ }^{2}$ \\ ${ }^{1}$ Instituto de Geociencias \\ ${ }^{2}$ Instituto de Pesquisas Ambientais
}

October 27, 2021

\begin{abstract}
Groundwater-Surface water interactions in alluvial plains facing morphological features are the subject of the study. Considered transitions zones, alluvial plains have different morphological features interfering with groundwater flow and hydrochemistry. The alluvial plain of Mogi Guaçu river (southeastern Brazil) presented topography-controlled groundwater flow, nevertheless, natural levees, wet fields, oxbow lakes, and abandoned meanders can control local flow and interfere in discharges points of the main river. Two sampling water campaigns were done in the dry and wet season for physicochemical and natural isotopes analysis, collecting in total 44 groundwaters samples from monitoring wells and eight water samples from the river, creek, and lake. The groundwaters in wet fields and terraces, and surface waters from creek and lake presented low mineralization (EC from 8 to $37 \mu \mathrm{S} . \mathrm{cm}^{-1}$ ), $\mathrm{pH}$ acidic (4.98 to 5.8), and essentially $\mathrm{Ca}$ and $\mathrm{Na}-\mathrm{HCO}_{3}$ composition. River waters samples presented $\mathrm{pH}$ between 5.92 e 7.69 (acidic in the rainy season and basic in the dry season), and EC from 24.2 and $181.1 \mu \mathrm{S} / \mathrm{cm}$ (lower values in the wet season), $\mathrm{Na}-\mathrm{HCO}_{3}$ and $\mathrm{Na}-\mathrm{HCO}_{3}-\mathrm{SO}_{4}$ (dry season) and $\mathrm{Ca}-\mathrm{HCO}_{3}$ and $\mathrm{Na}-\mathrm{HCO}_{3}$ (rainy season) compositions. In dry season groundwaters composition showed evolution from sodium mixed $\left(\mathrm{SO}_{4}-\mathrm{HCO}_{3}\right)$ to bicarbonate waters and higher mineralization; in wet season waters varied from $\mathrm{Ca}$ to $\mathrm{Na}-\mathrm{HCO}_{3}$ composition and low mineralization, denoting dilution due to rainwater infiltration. Closer to the river margins, in abandoned meanders and oxbows, the groundwaters have increased values of EC and major ions indicating GW-SW mixtures, and effluent-influent changes (descendent and ascendent flux) in wet and dry seasons, respectively. Natural isotopes in groundwaters imply meteoric origin, without evaporation during recharge and high d-excess can be influenced by continental air masses and Amazonia Basin low-level jet. Shallow water table, permeable siltysand material of vadose zone, flat terrain, and pristine conditions can contribute to direct infiltration of rainwaters, recharging the shallow aquifer.
\end{abstract}

\section{Hosted file}

Article-Correaetal-ORIGINAL_zero.docx available at https://authorea.com/users/443260/ articles/543276-hydrogeological-hydrochemical-and-natural-isotopes-evaluation-ofgroundwater-and-surface-water-interactions-in-the-alluvial-plain-tropical-region-ofsoutheastern-brazil 

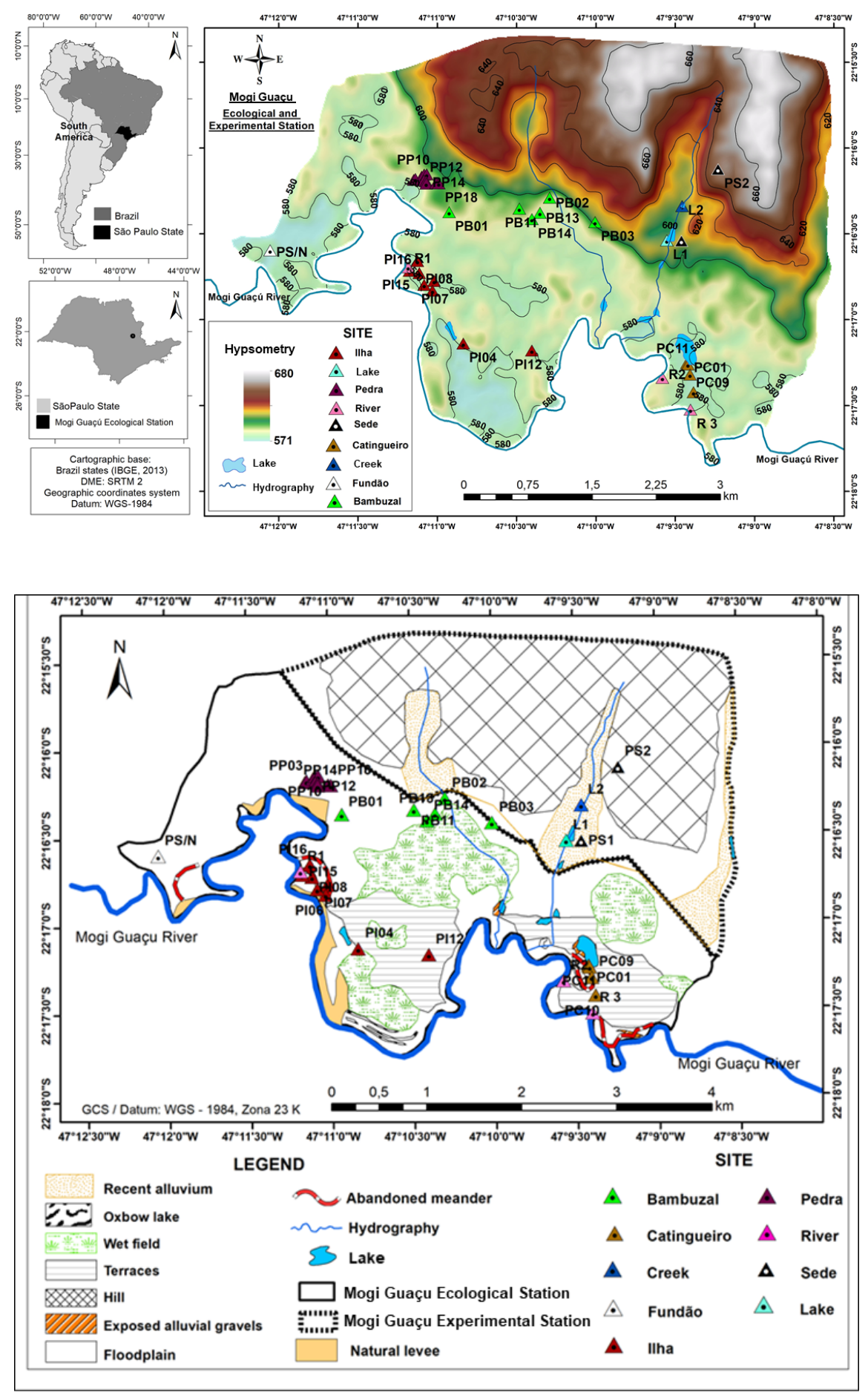

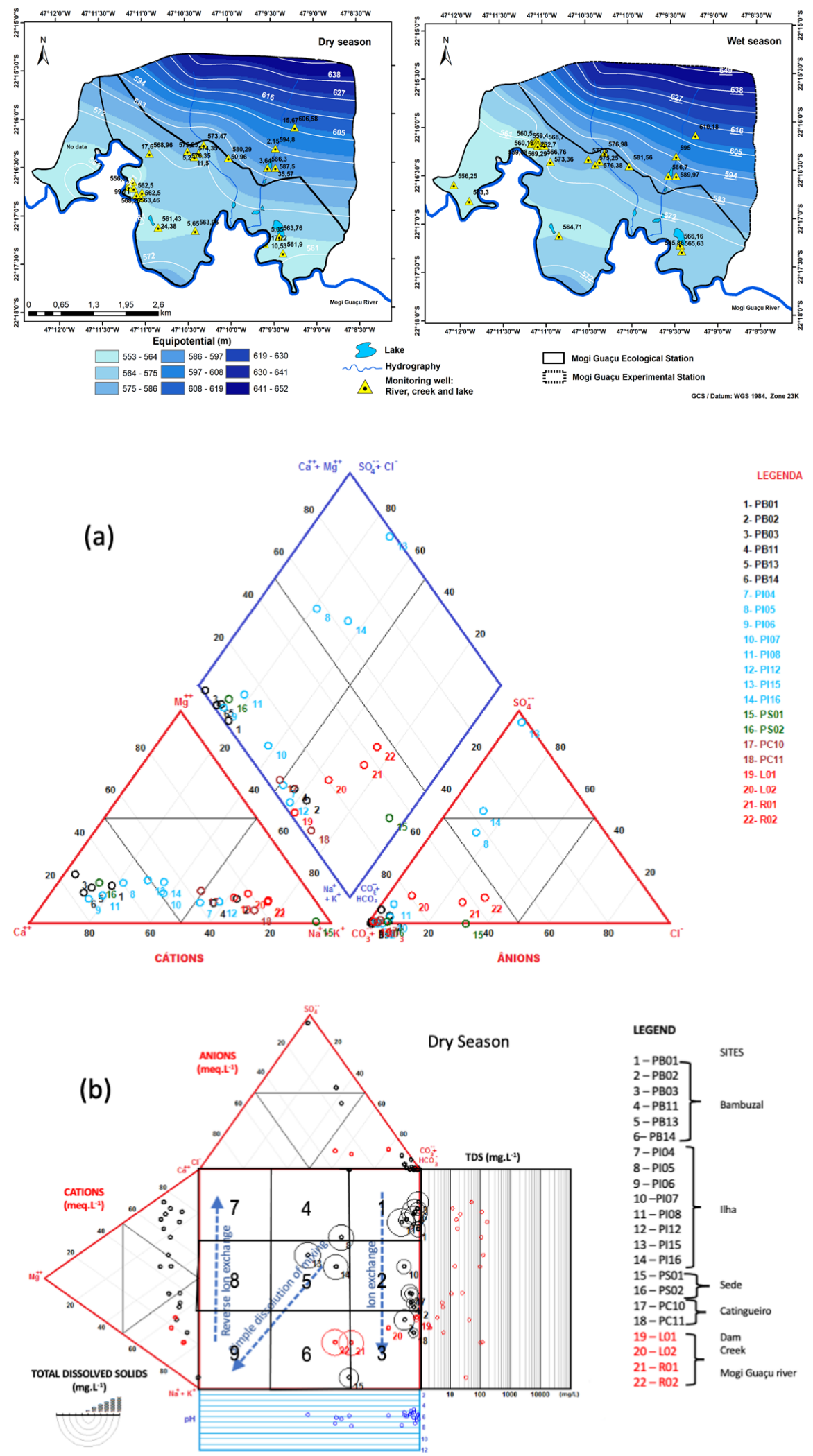

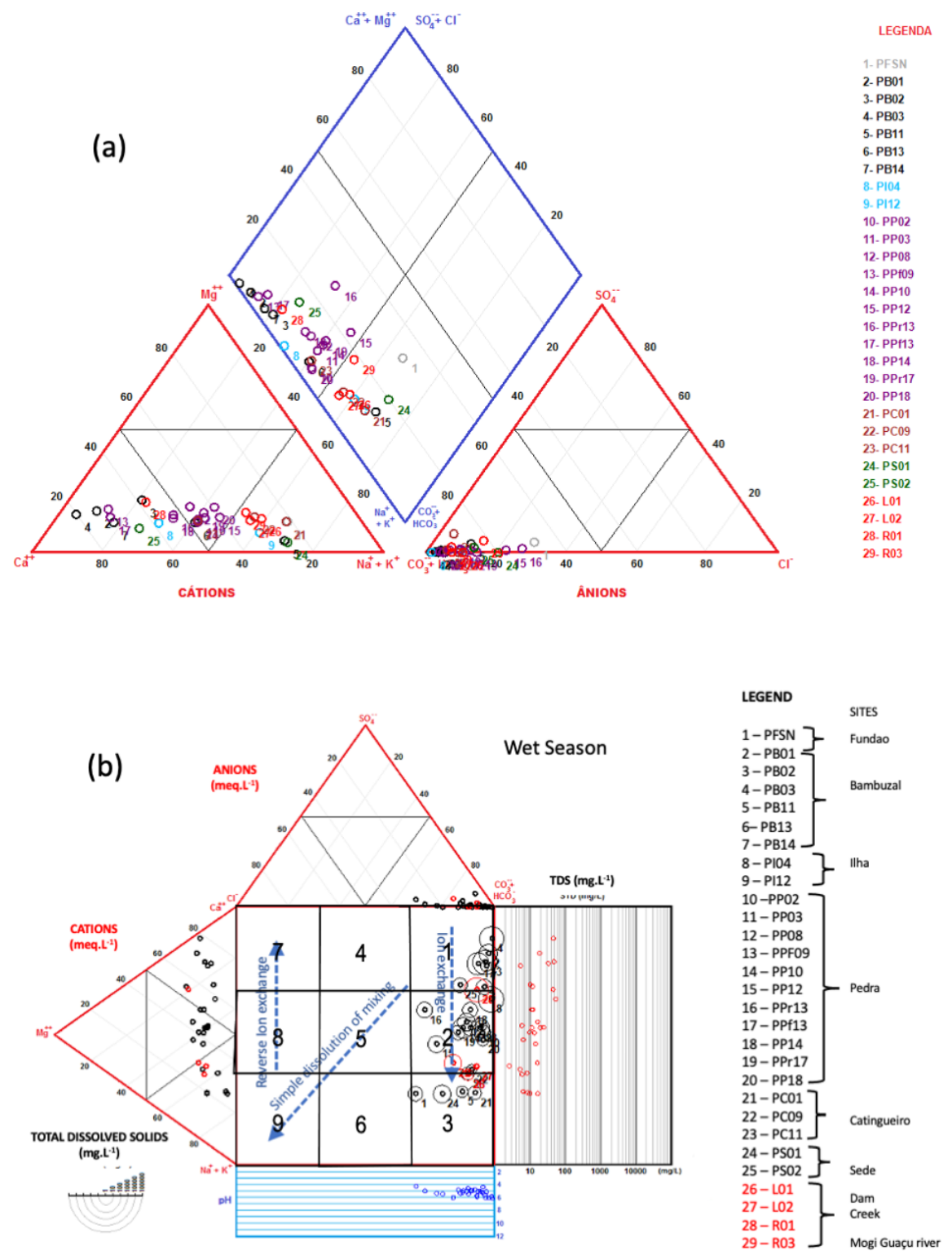

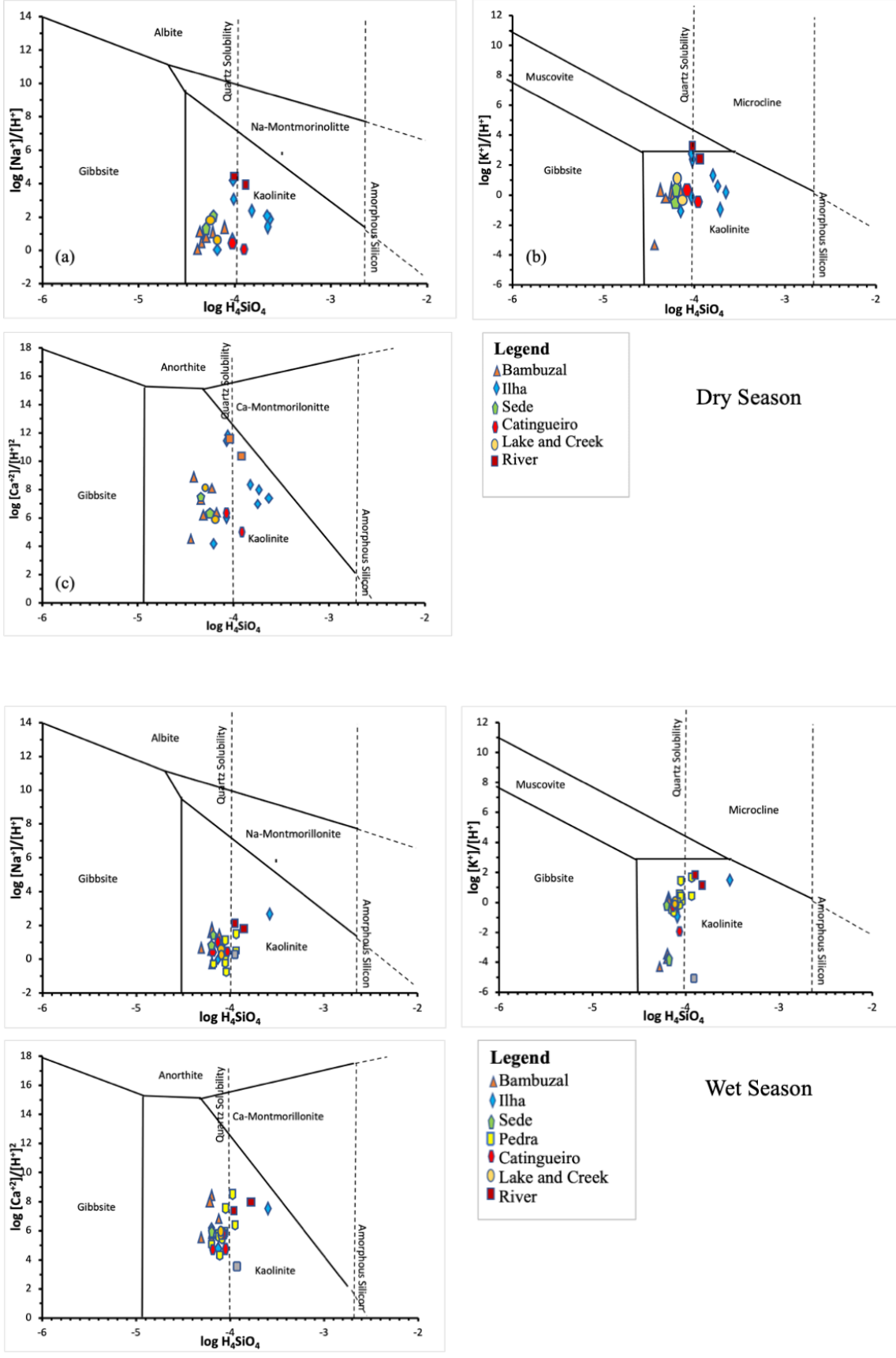

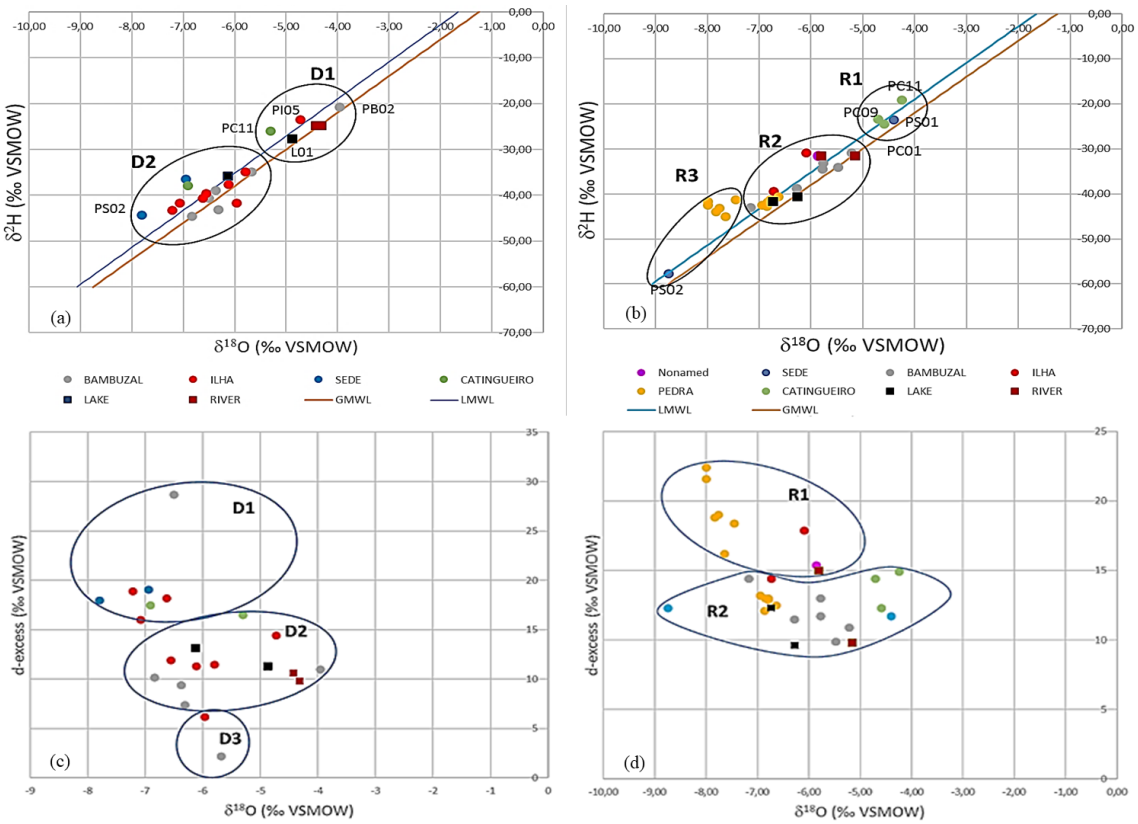

\section{Hosted file}

Table 1 - dry season.docx available at https://authorea.com/users/443260/articles/543276hydrogeological-hydrochemical-and-natural-isotopes-evaluation-of-groundwater-andsurface-water-interactions-in-the-alluvial-plain-tropical-region-of-southeastern-brazil

\section{Hosted file}

Table 2 - wet season.docx available at https://authorea.com/users/443260/articles/543276hydrogeological-hydrochemical-and-natural-isotopes-evaluation-of-groundwater-andsurface-water-interactions-in-the-alluvial-plain-tropical-region-of-southeastern-brazil

\section{Hosted file}

Table 3 - Pearson - dry season.docx available at https://authorea.com/users/443260/articles/ 543276-hydrogeological-hydrochemical-and-natural-isotopes-evaluation-of-groundwater-andsurface-water-interactions-in-the-alluvial-plain-tropical-region-of-southeastern-brazil

\section{Hosted file}

Table 4- Pearson - wet season.docx available at https://authorea.com/users/443260/articles/ 543276-hydrogeological-hydrochemical-and-natural-isotopes-evaluation-of-groundwater-andsurface-water-interactions-in-the-alluvial-plain-tropical-region-of-southeastern-brazil

\section{Hosted file}

Table 5 - SI and Gibbs dry season.docx available at https://authorea.com/users/443260/ articles/543276-hydrogeological-hydrochemical-and-natural-isotopes-evaluation-ofgroundwater-and-surface-water-interactions-in-the-alluvial-plain-tropical-region-ofsoutheastern-brazil

\section{Hosted file}

Table 6 - SI and Gibbs wet season.docx available at https://authorea.com/users/443260/ articles/543276-hydrogeological-hydrochemical-and-natural-isotopes-evaluation-of- 
groundwater-and-surface-water-interactions-in-the-alluvial-plain-tropical-region-ofsoutheastern-brazil

\section{Hosted file}

Table 7 - SI - dry season.docx available at https://authorea.com/users/443260/articles/ 543276-hydrogeological-hydrochemical-and-natural-isotopes-evaluation-of-groundwater-andsurface-water-interactions-in-the-alluvial-plain-tropical-region-of-southeastern-brazil

\section{Hosted file}

Table 8 - SI - wet season.docx available at https://authorea.com/users/443260/articles/ 543276-hydrogeological-hydrochemical-and-natural-isotopes-evaluation-of-groundwater-andsurface-water-interactions-in-the-alluvial-plain-tropical-region-of-southeastern-brazil 